Available online: journal.ipb.ac.id/index.php/jphpi

\title{
KARAKTERISTIK KIMIAWI TEPUNG IKAN MOLLY, POECILIA LATIPINNA (LESUEUR 1821)
}

\author{
Hasnidar dan Andi Tamsil \\ Jurusan Budidaya Perairan Fakulas Perikanan dan Ilmu Kelautan Universitas Muslim Indonesia \\ Jalan Urip Sumohajo KM 04, Kampus II UMI Makassar \\ *Korespondensi: hasnidar.yasin@umi.ac.id \\ Diterima: 5 Agustus 2020/ Disetujui: 31 Agustus 2020
}

Cara sitasi: Hasnidar, Tamsil A. 2020. Karakteristik kimiawi tepung ikan molly, Poecilia latipinna (Lesueur 1821). Jurnal Pengolahan Hasil Perikanan Indonesia. 23(2): 392-401.

\begin{abstract}
Abstrak
Penelitian ini bertujuan untuk menentukan kandungan gizi tepung ikan molly, P. latipinna (Lesueur 1821) sebagai bahan pakan ikan, udang dan ternak. Sampel ikan dibersihkan, dikeringkan di bawah sinar matahari selama 12 jam, diblender menjadi tepung selanjutnya diuji proksimat. Hasil analisis menunjukkan bahwa tepung ikan molly mengandung protein; lemak; serat kasar; abu, air secara berturut-turut sebagai berikut: 66,40\%; 12,52\%; 0,80\%; 15,51\% dan 3,70\%; asam amino esensial yaitu: lisina 4,99\%; leusina 4,27\%; fenilalanina 2,64\%; valina 2,63\%; treonina 2,50\%; dan histidina 1,49\%. Asam lemak esensial terdiri dari kelompok asam lemak omega-3 yaitu: asam dekosakeksanoat (DHA) 0,09\%; asam eikosapentanoat (EPA) $0,03 \%$ dan asam linolenat (HUFA) 0,21\%. Kelompok asam lemak omega 6 terdiri atas asam linoleat (LA) 0,25\% dan arakidonat (AA) $0,04 \%$. Tepung ikan molly secara kuantitas dan kualitas sangat baik sebagai bahan pakan sumber protein, asam amino dan asam lemak esensial untuk pakan ikan, udang dan ternak.
\end{abstract}

Kata kunci: asam amino, asam lemak, esensial, protein, tepung ikan molly

\section{Chemical Characteristics of Molly Poecilia latipinna (Lesueur 1821) Flour}

\begin{abstract}
The study was aimed to analyze the nutrient content of molly P. latipinna (Lesueur 1821) flour as feed ingredients for fish, shrimp and livestock. Fish samples were cleaned, dried in the sun for 12 hour, blended into flour and their proximate compositions were measured. The analysis showed that the fish meal contained protein, fat, crude fiber, ash, moisture as follows $66.40 \% ; 12.52 \% ; 0.80 \% ; 15.51 \%$ and $3.70 \%$, respectively. The fish meal also contained essential amino acids, namely: lysine 4.9\%; lucine $4.27 \%$; phenylalanine $2.64 \%$; valine $2.64 \%$; threonine $2.5 \%$; and histidine $1.49 \%$. The fatty acids consisted of omega-3 fatty acid groups: decosacexanoic acid (DHA) $0.09 \%$; eicosapentanoic acid (EPA) $0.03 \%$ and linolenic acid (HUFA) $0.21 \%$ as well as omega 6 fatty acids: linoleic acid (LA) $0.25 \%$ and arachidonic (AA) $0.04 \%$. The molly flour is a good source of protein, amino acids and essential fatty acids for fish, shrimp and livestock feed.
\end{abstract}

Keywords: amino acids, fatty acids, essential, protein, sailfin molly meal 


\section{PENDAHULUAN}

Ikan molly, Poecilia latipinna (Lesueur 1821) hidup secara alami di air payau (Johnson, 1981), berukuran kecil rata-rata ukuran ikan jantan $51 \mathrm{~mm}$ dan betina $46 \mathrm{~mm}$, ovovivipar yaitu melahirkan anaknya dengan jumlah \pm 32 ekor larva/induk (Tamsil dan Hasnidar 2019). Ikan ini berkembangbiak sangat cepat, hidup liar sehingga menjadi hama di tambak (Lockwood et al. 2007, Tamsil dan Hasnidar 2019). Hama menjadi kendala produksi, ada tiga jenis kerugian yang ditimbulkannya karena bersifat sebagai predator, penyaing dan pengganggu (Fahmi 2000). Ikan molly dikategorikan sebagai hama penyaing karena mengurangi efisiensi pemberian pakan dan ruang gerak serta pemenuhan oksigen pada organisme budidaya.

Pemberantasan atau penanggulangan ikan molly di tambak Kabupaten Maros dilakukan secara mekanis yaitu dengan menangkap menggunakan jaring yang dipasang pada pintu air. Cara ini menguntungkan karena selain dapat memberikan nilai tambah bagi petani tambak sebagai hasil sampingan (Fahmi 2000), juga tidak menimbulkan dampak yang merugikan terhadap lingkungan. Berdasarkan informasi di lapangan, hasil tangkapan ikan molly tersebut dimanfaatkan secara langsung menjadi makanan ternak (itik) dan kalau jumlahnya banyak dibuang begitu saja. Potensi ikan molly yang terbuang ini dapat diolah menjadi tepung ikan untuk dimanfaatkan sebagai sumber protein hewani dan menjadi bahan baku pakan ikan dan ternak setempat. Bahan baku pakan harus memenuhi persyaratan tertentu yaitu : bahan tidak mengandung racun, kandungan gizi baik, tidak bersaing dengan kebutuhan pangan manusia, tersedia secara kontinyu, harga bahan murah (Sutikno et al. 2017).

Bahan baku pakan ikan dan udang selama ini masih bergantung pada komponen impor, yakni tepung ikan. Impor tepung ikan hampir mencapai 50\% dari kebutuhan. Impor tepung ikan berasal dari negara Thailand dan Vietnam. Tingginya jumlah tepung ikan yang diimpor menyebabkan harga tepung ikan semakin mahal sehingga menjadikan kendala bagi perkembangan usaha budidaya perikanan. Pemerintah mempunyai target produksi perikanan budidaya nasional tahun 2019 diproyeksi mencapai 31,3 juta ton dengan produksi ikan 11,7 juta ton, untuk mencapai target itu dibutuhkan setidaknya 14 juta ton pakan ikan (Asdary et al. 2019). Isu pakan merupakan bagian penting yang perlu menjadi fokus perhatian bersama karena pakan merupakan penyusun terbesar biaya produksi usaha budidaya yang lebih dari 70\%. Oleh karena itu, untuk mengatasi hal tersebut diperlukan alternatif sumber protein hewani yang harganya relatif murah, tersedia setiap waktu, dan kualitasnya baik (Utomo et al. 2013).

Protein sangat diperlukan untuk pertumbuhan dan menghasilkan tenaga. Protein hewani lebih mudah dicerna daripada protein nabati, hal ini disebabkan karena protein nabati terbungkus dalam dinding selulosa yang sukar dicerna (Sutikno et al. 2017), selain itu sumber protein hewani memiliki kandungan asam amino esensial yang lebih lengkap (Ikhfa 2017). Pakan sumber protein adalah bahan pakan yang memiliki kandungan protein minimal 20\% (Ikhfa 2017), selain kandungan protein yang tinggi mutu sumber pakan juga tergantung pada macam dan jumlah asam amino yang dikandungnya (Ihu 2011). Asam amino yang mutlak diperlukan dan tidak dapat disintesis dalam tubuh ikan sehingga harus tersedia dalam pakan disebut asam amino esensial (Abdullah et al. 2013). Kesepuluh asam amino esensial adalah arginin, fenilalanin, histidin, isolusin, lusin, lisin, metionin, treonin, triptofan, valin (Abdullah et al. 2017). Lemak berfungsi sebagai sumber energi dan dapat menjadi pengganti sumber energi yang disumbangkan oleh protein, sehingga pemanfaatan protein lebih optimal untuk pertumbuhan. Selain itu, lemak sebagai sumber asam lemak esensial yang berperan penting dalam membran sel. Kebutuhan ikan akan lemak bervariasi antara 4-18\% (Sutikno et al. 2017). Nilai gizi lemak dipengaruhi oleh kandungan asam lemak esensialnya yaitu asam-asam lemak tak jenuh atau PUFA (Poly Unsaturated Fatty Acid) antara lain asam oleat, asam linoleat dan asam linolenat (Jacoeb et al. 2020; Nurjanah et al. 2015). 
Informasi mengenai kandungan gizi ikan molly sebagai bahan baku pakan ikan/ udang dan ternak belum ada, oleh karena itu penelitian ini bertujuan untuk menentukan kandungan protein, lemak, karbohidrat, serat kasar, abu dan air; asam amino dan asam lemak esensial. Diharapkan hasil penelitian ini menjadi bahan informasi untuk pemanfaatan ikan molly sebagai bahan baku pakan ikan, udang dan ternak lokal.

\section{BAHAN DAN METODE Bahan dan Alat}

Bahan yang digunakan adalah ikan molly yang diambil di tambak PT BOSOWA ISUMA yang terletak di Desa Mattirotasi, Kecamatan Maros Baru Kabupaten Maros (Figure 1), analisis proksimat meliputi akuades, katalis selenium, $\mathrm{H}_{2} \mathrm{SO}_{4}$ (Merck $\mathrm{KGa}$ ), $\mathrm{H}_{3} \mathrm{BO}_{3}$ (Merck) 2\%, kertas saring, kapas bebas lemak, $\mathrm{HCl}$ (Merck) 0,1 (Merck) N, NaOH (Merck) $40 \mathrm{~mL}$, pelarut heksana (Sigma Aldrich), bromcresol green (Sigma) 0.1\%, dan methyl red $0.1 \%$ (Sigma), aquades, $\mathrm{Pa}$. chloroform dan $P a$. methanol, $\mathrm{NaOH}$ (Merck) 0,5 N dalam metanol, $\mathrm{BF}_{3}$ (Merck), $\mathrm{NaCl}$ jenuh (Merck), n-heksana (Merck), dan $\mathrm{Na}_{2} \mathrm{SO}_{4}$ anhidrat (Merck). Alat yang digunakan adalah HLPC (Shimadzu 2000) dn GC ( Shimadzu 2000)

\section{Metode Penelitian}

Ikan molly adalah jenis ikan yang berukuran kecil sehingga tidak ada bagian yang dibuang. Sampel dibersihkan selanjutnya dikeringkan di bawah sinar matahari, waktu pengeringan \pm 12 jam (tergantung kepada intensitas matahari, estimasi kadar air $<10 \%$ ). Selanjutnya ikan tersebut diblender menjadi tepung, dan siap untuk dianalisis. Protein, lemak, abu, serat kasar, dan air menggunakan metode AOAC (2005).

\section{Analisis asam lemak (Abdullah et al. 2013)}

Analisis diawali penyiapan $20 \mathrm{mg}$ ekstrak lemak sampel dalam tabung bertutup teflon, lalu dipanaskan dalam penangas air selama 20 menit. Tahap berikutnya adalah penambahan larutan BF3 20\% $2 \mathrm{~mL}$ dan $5 \mathrm{mg} / \mathrm{mL}$ standar internal dan dipanaskan selama 20 menit. Campuran kemudian didinginkan dan ditambahkan $2 \mathrm{~mL} \mathrm{NaCl}$ jenuh dan $1 \mathrm{~mL}$ isooktan, lalu campuran dikocok dengan baik. Lapisan isooktan yang terbentuk dipindahkan dengan bantuan pipet tetes ke dalam tabung berisi sekitar 0,1 $\mathrm{g} \mathrm{Na}_{2} \mathrm{SO}_{4}$ anhidrat, dan dibiarkan 15 menit. Fase cair yang terbentuk dipisahkan, sedangkan fase minyak yang terbentuk diinjeksikan ke instrumen GC sebanyak $1 \mu \mathrm{L}$, setelah sebelumnya dilakukan penginjeksian $1 \mu \mathrm{L}$ campuran standar FAME (Supelco 37 component fatty acid methyl ester mix).

\section{Analisis asam amino (Abdullah et al. 2013)}

Komposisiasamaminoditentukan dengan menggunakan HPLC. Sebelum digunakan,

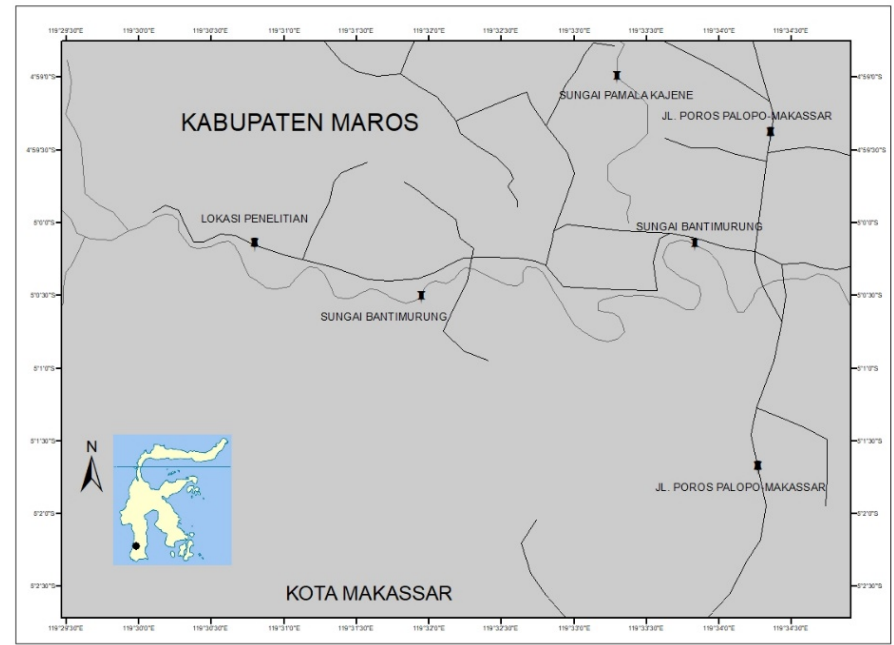

Figure 1 Location for molly fish sampling in the PT Bosowa Isuma in Desa Mattirotasi, Kecamatan Maros Baru, Kabupaten Maros South Sulawesi 
perangkat HPLC harus dibilas dulu dengan eluen yang akan digunakan selama 2 sampai 3 jam. Begitu pula syringe yang akan digunakan dibilas dengan akuades. Analisis asam amino dengan menggunakan HPLC terdiri atas 4 tahap, yaitu tahap pembuatan hidrolisat protein, tahap pengeringan, tahap derivatisasi, dan tahap injeksi serta analisis asam amino. a. Tahap pembuatan hidrolisat protein Sampel ditimbang sebanyak $5 \mathrm{~g}$ dan dihancurkan. Sampel yang telah hancur dihidrolisis asam menggunakan $\mathrm{HCl} 6 \mathrm{~N}$ sebanyak $10 \mathrm{~mL}$ yang kemudian dipanaskan dalam oven pada suhu $110{ }^{\circ} \mathrm{C}$ selama 24 jam. Pemanasan dalam oven dilakukan untuk menghilangkan gas atau udara yang ada pada sampel agar tidak mengganggu kromatogram yang dihasilkan. Pemanasan dilakukan untuk mempercepat reaksi hidrolisis. b. Tahap pengeringan Sampel $25 \mu \mathrm{L}$ dimasukkan ke tabung uji dan ditambahkan $25 \mu \mathrm{L}$ larutan pengering. Larutan pengering dibuat dari methanol, natrium asetat dan triethylamine (TEA) dengan sampel 2:2:1 kemudian dikeringkan menggunakan rotary evaporator selama 15-30 menit. c. Tahap derivatisasi Larutan derivatisasi sebanyak $25 \mu \mathrm{L}$ ditambahkan pada hasil pengeringan, larutan derivatisasi dibuat dari methanol, picotiocianat (PITC) dan tryethilamine dengan sampel 1:1:2 kemudian dibiarkan selama 20 menit pada suhu ruang. Kemudian tambahkan $25 \mu \mathrm{L}$ natrium asetat $1 \mathrm{M}$, selanjutnya campuran tersebut disaring menggunakan kertas saring Whatman. d. Injeksi ke HPLC Hasil saringan sebanyak 5 $\mu \mathrm{L}$ diinjeksikan ke dalam HPLC. Pemisahan semua asam amino ditunggu sampai selesai. Waktu yang diperlukan sekitar 25 menit. Perhitungan konsentrasi asam amino yang ada pada bahan dilakukan dengan pembuatan kromatogram standar dengan menggunakan asam amino yang telah siap pakai yang mengalami perlakuan yang sama dengan sampel. Kandungan asam amino dalam bahan dapat dihitung dengan rumus:

\% Assam amino = Luas arees sampel x C X F x BM 1 100\% Luas area standar x bobot sampel

Keterangan:

$\mathrm{C}=$ Konsentrasi standar asam amino $(0,5$ $\mu \mathrm{mol} / \mathrm{mL}$ )

$\mathrm{FP}=$ Faktor pengenceran $(5 \mathrm{~mL})$
$\mathrm{BM}=$ Bobot molekul dari masing-masing asam amino $(\mathrm{g} / \mathrm{mol})$

Kondisi alat HPLC saat berlangsungnya analisis asam amino sebagai berikut: Temperatur : $27^{\circ} \mathrm{C}$ (suhu ruang) Jenis kolom HPLC : P1 Cotag Amino Acid Kecepatan alir eluen : $0.5 \mathrm{~mL} / \mathrm{menit}$ Tekanan : 3000 psi

Fase gerak : Buffer fosfat, Asetonitril Detektor/ Panjang gelombang : Fluoresensi/ $272 \mathrm{~nm}$

\section{Analisis Data}

Hasil uji kimia (proksimat), asam amino dan asam lemak esensial tepung ikan molly dianalisis secara deskriptif. Untuk uji kimia, hasilnya dibandingkan dengan kualitas tepung ikan yang direkomendasikan sesuai SNI 01-2715-1996, dengan klasifikasi menjadi 3 level kualitas.

\section{HASIL DAN PEMBAHASAN Uji Proksimat Tepung ikan Molly}

Tepung ikan molly adalah produk tepung ikan yang berasal dari seluruh bagian ikan tanpa membuang kepala dan isi perut. Hasil uji proksimat/kimia tepung ikan molly dibandingkan dengan SNI (01-2715-1996) dapat disajikan pada Table 1. Kadar protein tepung ikan molly memenuhi syarat sebagai sumber protein berdasarkan Standar Nasional Indonesia (SNI 01-2715-1996) pada level mutu I (kategori sangat baik) yaitu 65\% min. Kandungan lemaknya adalah $12,52 \%$, berdasarkan SNI yaitu mutu III (kategori kurang baik). Kadar serat kasar tepung ikan molly sebesar $0,80 \%$, nilai ini lebih kecil jika dibanding dengan kadar serat kasar berdasarkan SNI mutu I yaitu 1,5\% maks. Kadar abu sebesar $15,51 \%$ dan kadar air $3,70 \%$, nilai tersebut berdasarkan SNI berada pada mutu I.

Menurut Boniran (1999), kriteria tepung ikan yang berkualitas baik adalah mengandung protein kasar 58-68\% dan kadar air 5,5-8,5\%. Ikan memiliki kadar protein yang tinggi karena protein tubuhnya berfungsi sebagai sumber energi dan komponen struktur tubuh (Damayanti 2005). Keunggulan protein hewani dibandingkan protein nabati adalah selain kadar proteinnya tinggi, kualitas 
Table 1 Proximate test result of molly fish meal

\begin{tabular}{|c|c|c|c|c|}
\hline \multirow{2}{*}{ Composition } & \multirow{2}{*}{$\begin{array}{l}\text { Molly } \\
\text { fish meal }\end{array}$} & \multicolumn{3}{|c|}{$\begin{array}{l}\text { Indonesian National Standard (01- } \\
\text { 2715-1996 }\end{array}$} \\
\hline & & Quality I & Quality II & Quality III \\
\hline Water (\%) $\max$ & 3.70 & 10.0 & 12 & 12 \\
\hline Crude Protein (\%) min & 66.40 & 6.5 & 55 & 45 \\
\hline Crude Fiber (\%) max & 0.80 & 1.5 & 2.5 & 3 \\
\hline Ash (\%) $\max$ & 15.51 & 20.0 & 25 & 30 \\
\hline Fat (\%) $\max$ & 12.5 & 8.0 & 10 & 12 \\
\hline
\end{tabular}

proteinnya juga sangat bagus karena memiliki kandungan asam amino esensial yang lebih lengkap serta proteinnya mudah dicerna. Menurut Hafiluddin et al. (2014), kandungan protein ikan erat kaitannya dengan kandungan lemak dan air. Ikan membutuhkan kadar protein yang relatif tinggi dan komposisi asam amino yang sesuai dengan kebutuhannya melalui pakannya (Rabegnatar \& Tahapari 2002; Trilaksani et al. 2006). Beberapa faktor yang berpengaruh terhadap kebutuhan protein ikan antara lain adalah: spesies, ukuran ikan, kuantitas dan kualitas protein pakan, energi, komposisi pakan secara keseluruhan dan kualitas perairan. Oleh karena dipengaruhi oleh banyak faktor tersebut maka kebutuhan protein ikan juga sangat bervariasi yaitu antara 25-50\% (Lovell 1989).

Senyawa organik kedua yang menjadi sumber makanan setelah protein adalah lemak (Gultom et al. 2015). Kelebihan lemak dari ikan yaitu sebagai sumber asam lemak esensial (Samsundari 2007). Kandungan lemak tepung ikan molly sebesar $12,5 \%$, nilai ini berdasarkan SNI berada pada level mutu III. Kadar lemak yang tinggi dalam pakan terkait dengan daya awet pakan (Puspowardoyo \& Djarijah 2002). Daya awet akan menurun apabila kadar lemak bahan pakan semakin meningkat, proses penurunan kualitas pakan akibat kadar lemak yang tinggi ditandai dengan bau dan rasa tengik. Menurut Gultom et al (2015), lemak apabila dibiarkan tanpa perlakuan akan mudah terhidrolisis. Sifat lemak antara lain adalah tidak larut dalam air tetapi larut dalam pelarut-pelarut organik tertentu. Setiap jenis ikan memiliki kadar lemak yang berbedabeda, salah satu yang mempengaruhinya adalah kadar air. Semakin tinggi kadar air bahan maka kadar lemak menurun cenderung menurun (Husni dan Brata 2005).

Kadar serat kasar tepung ikan molly sebesar $0,80 \%$, nilai ini lebih kecil jika dibanding dengan kadar serat kasar berdasarkan SNI mutu I yaitu 1,5\% maks. Serat kasar pada konsentrasi tertentu dibutuhkan untuk membantu proses pencernaan dan ekskresi sisa-sisa pakan (Megawati et al. 2012). Ikan kurang mampu mencerna serat dalam pakan, karena dalam usus ikan tidak terdapat mikroba yang dapat memproduksi enzim selulose (Halver 2002). Menurut Robinson et al. (2001), kebutuhan serat kasar dalam pakan ikan jumlahnya terbatas yaitu maksimum $7 \%$. Selanjutnya dijelaskan bahwa pada ikan jenis catfish, jumlah serat yang dapat digunakan dalam pakan yaitu kadar antara 3\% sampai 6\%. Semakin tinggi kadar serat kasar dalam pakan maka tingkat kecernaan pakan tersebut semakin rendah, akibatnya pakan tersisa yang tidak terkonsumsi semakin meningkat di dalam perairan. Hal tersebut sejalan dengan Watanabe (1988) mengemukakan bahwa pakan dengan kandungan serat kasar $>10 \%$ akan berpengaruh terhadap penurunan daya cerna dan penyerapan pakan, sisa metabolism meningkat sehingga berakibat pada penurunan kualitas air. Kadar serat kasar yang dapat menunjang pertumbuhan ikan yang optimum adalah $4 \%$ sampai $8 \%$ (Rukmana 1997).

Kadar abu tepung ikan molly sebesar $15,51 \%$, nilai tersebut berdasarkan SNI berada pada level mutu I atau kategori sangat baik. Indikator besarnya kandungan mineral bahan pakan menunjukkan kadar abu bahan tersebut 
(Jangkaru 1974), namun apabila kadarnya $>30 \%$ maka dianggap bahan tersebut kurang bagus.

Kadar air tepung ikan molly yaitu 3,70\%, nilai ini berdasarkan SNI berada pada level mutu I atau kategori sangat baik. Kadar air bahan pakan akan menentukan daya awet pakan, apabila mengandung banyak air maka pakan menjadi lembab, mudah ditumbuhi jamur sehingga kualitasnya menurun. Pakan yang berjamur akan berbahaya apabila diberikan pada ikan. Kadar air pada pakan sebaiknya tidak lebih besar dari 10\% (Sahwan 2002).

\section{Kandungan Asam Amino Esensial Tepung Ikan Molly}

Hasil pengujian asam amino esensial tepung ikan molly diperoleh ada enam jenis yaitu: histidina, treonina, leusina, lisina, valina, fenilalanina, lebih jelasnya disajikan pada Table 2.

Table 2 Essential amino acids in molly fish meal

\begin{tabular}{lr}
\hline Essential Amino Acids & Amount (\%) \\
\hline Histidine & 1.49 \\
Threonine & 2.00 \\
Leucine & 4.27 \\
Lisine & 4.99 \\
Valine & 2.63 \\
Phenilalanine & 2.64 \\
\hline
\end{tabular}

Bahan pangan yang mengandung protein cukup tinggi belum tentu memiliki kualitas protein yang baik. Kualitas protein terkait dengan asam amino yang dikandungnya. Klasifikasi asam amino berdasarkan kemampuan tubuh untuk mensintesis dan kebutuhan metaboliknya, maka dikenal dengan asam amino esensial dan non esensial. Asam amino esensial tidak dapat disintesis dalam tubuh hewan atau jumlah yang dapat disintesis tidak cukup untuk memenuhi kebutuan fisiologis ikan untuk tumbuh dan berkembang, dengan demikian keberadaannya perlu dipasok dari pakan (Sitompul 2004).

Tepung ikan molly mengandung enam asam amino esensial yaitu lisina $4,9 \%$; leusina $4,2 \%$; fenilalanina $2,64 \%$; valina
2,63\%; treonina 2,5\%: dan histidina 1,4\%. Menurut Meilisza dan Subamia (2016), asam amino esensial yang paling banyak dibutuhkan adalah lisin (Miles dan Chapman 2007). Menurut Sundari et al. (2004), lisina merupakan asam amino esensial yang sangat berguna bagi tubuh. Lisina adalah prekusor untuk biosintesis karnitin, sedangkan karnitin merangsang proses $\beta$-oksidasi dari asam lemak rantai panjang yang terjadi di mitokondria. Penambahan lisina ke dalam pakan diharapkan dapat meningkatkan terbentuknya karnitin, dengan demikian lemak tubuh yang mengalami $\beta$-oksidasi semakin meningkat, sehingga mengakibatkan kadar lemak dan kolesterol daging rendah. Selain itu, lisina memiliki peran penting karena merupakan bagian dari komposisi dasar antibodi, memperkuat sirkulasi dan menjaga pertumbuhan sel yang normal (Pratama et al. 2018). Selanjutnya dijelaskan bahwa lisina adalah jenis asam amino pembatas pada protein nabati, kandungan yang dibutuhkan dalam ransum ikan berkisar antara 4\%-6\%. Penelitian pada ikan hias mas koki (C. auratus) diketahui kebutuhan lisina (\% dalam protein) sekitar 11,8 dan pada ikan tilapia (Sarotherodon mosambicus) sekitar 3,8; african catfish 5,7; channel catfish 5,0-5,1; sedangkan benih salmon 2,0 (Mertz 1969; Harding et al. 1977; Robinson et al. 1981; Jauncey 1983; Fiogbe \& Kestemont 1995; dan Fagbenro et al. 1999). Kebutuhan lisin untuk pakan ternak yaitu berkisar 0,45-0,85\% (Parkhurst \& Mountney 1988). Berdasarkan kandungan lisin pada tepung ikan molly yaitu $4,9 \%$, maka tepung ikan molly baik digunakan sebagai sumber lisin untuk pakan ternak.

Kandungan asam amino tertinggi kedua adalah leusin. Leusin merupakan molekul penting dan memiliki banyak fungsi baik pada manusia maupun pada ikan. Pada manusia leusin berperan merangsang sintesis protein otot, mengobati stress, trauma, dan luka bakar (Vijayan et al. 2016); memacu fungsi otak, menurunkan kadar gula darah, membantu penyembuhan tulang, otot dan kulit (Harli 2008); menjaga sistem imun (Edison 2009). Sedangkan pada ikan, leusin diduga berfungsi untuk merangsang organ penciuman khususnya dalam mendeteksi 
makanan di dalam air seperti pada ikan kerapu (Rahayu et al. 2014). Kadar leusina pada ikan berbeda-beda, tepung ikan molly sebesar 4,27\% hampir sama pada ikan gabus yaitu 4,49\% (Prastari et al. 2017); lebih rendah dibandingkan pada ikan lele yaitu 9,31\% (Arrahman 2018); dan lebih tinggi daripada ikan kembung yaitu 0,13\% (Rahayu 2014).

Fenilalanina merupakan asam amino aromatik sehingga sangat bermanfaat pada ikan khususnya yang mengandalkan organ penciuman ketika mencari makan. Karena berperan merangsang napsu makan maka fenilalanin dapat meningkatkan pertumbuhan ikan (Rahayu et al. 2014). Tepung ikan molly mengandung fenilalanina sebesar 2,64\%; ikan gabus 2,44\% (Prastari et al. 2017); ikan lele 4,63\% (Arrahman 2018).

Tepung ikan molly mengandung valina sebesar 2,63\%; ikan gabas $2,76 \%$ (Prastari et al. 2017). Sumarjo (2009) melaporkan bahwa valina juga berperan sebagai perangsang nafsu makan ikan. Treonina dan histidina adalah dua jenis asam amino esensial yang kadarnya ditemukan pada tepung ikan molly masing-masing sebesar 2,63\% dan 1,49\%; ikan gabus 2,08\% dan 1,35\% (Prastari et al. 2017). Treonina dan histidina mempunyai peran sama yaitu selain meningkatkan pertumbuhan ikan seperti pada ikan lele, ikan mas dan salmon (Rahayu et al. 2014), juga berperan memperbaiki jaringan yang rusak (Vijayan et al. 2016).

Tepung ikan molly mengandung 6 jenis asam amino esensial dari sepuluh asam amino esensial yang direkomendasikan, nilai konsentrasi yang relatif tinggi sehingga sangat baik dijadikan sebagai sumber asam amino esensil untuk pakan.

\section{Kandungan Asam Lemak Esensial Tepung Ikan Molly}

Hasil pengukuran asam lemak esensial tepung ikan molly disajikan pada Table 3. Kualitas lemak ikan ditentukan oleh kandungan asam lemak esensialnya terutama asam lemak tak jenuh atau PUFA (Poly Unsaturated Fatty Acid). Asam lemak ini disebut esensial karena sangat dibutuhkan oleh tubuh tetapi tidak dapat diproduksi sehingga harus disuplai dari makanan yang dikonsumsi. Asam lemak esensil termasuk dalam kelompok "omega" antara lain omega-3 dan omega-6 (Rasyid 2003).

Table 3 Types of essential fatty acids in molly fish

\begin{tabular}{lc}
\hline \multicolumn{1}{c}{ Fatty Acids } & Amount (\%) \\
\hline Omega 3 & 0.09 \\
DHA, docosahexanoic acid & 0.03 \\
EPA, eicosapentanoic acid & 0.21 \\
HUFA, linolenaic acid & \\
Omega 6 & 0.25 \\
LA, linoleic acid & 0.04 \\
AA, arachidonic acid
\end{tabular}

Tepung ikan molly mengandung omega-3 yaitu: asam dekosakeksanoat (DHA) 0,09\%; asam eikosapentanoat (EPA) $0,03 \%$ dan asam linolenat (HUFA) 0,21\%; sedangkan kelompok omega 6 yaitu: asam linoleat (LA) $0,25 \%$ dan arakidonat (AA) $0,04 \%$. Setiap spesies ikan membutuhkan asam lemak esensial yang berbeda-beda (Furuichi 1988), perbedaannya sangat dipengaruhi oleh habitat ikan tersebut. Ikan yang hidup di laut lebih memerlukan asam lemak omega-3, sedangkan ikan yang hidup di air tawar ada yang hanya membutuhkan asam lemak omega-3 atau kombinasi asam lemak omega-3 dan omega-6 (Hepher 1990). Perbedaan utama antara ikan air tawar dan air laut adalah bahwa ikan air tawar membutuhkan asam linoleat, atau linolenat atau keduanya. Ikan air laut membutuhkan asam eikosapentonat (EPA) dan atau asam dekasohexaenat (DHA)(NRC 1993; Riry et al.2013). Menurut Sutikno (2017), asam lemak esensial berperan penting dalam membran sel, prekursor untuk maturasi dan moulting pada krustase. Selanjutnya dijelaskan ada empat jenis asam lemak ensensial yang dibutuhkan dalam pakan khususnya pakan udang yaitu asam linoleat $0,4 \%$; asam linolenat $0,3 \%$; EPA $0,4 \%$; serta DHA $0,4 \%$.

\section{KESIMPULAN}

Tepung Ikan molly memiliki kandungan protein sebesar 66,40\%; lemak 12,52\%; serat kasar 0,80\%; abu 15,51\% dan kadar air 
$3,70 \%$. Asam amino esensial yang terkandung pada tepung ikan molly yaitu lisina $4,99 \%$; leusin a4,27\%; fenilalanina 2,64\%; valina 2,63\%; treonin a2,50\%: dan histidina 1,49\%; selanjutnya asam lemak esensial terdiri dari kelompok asam lemak omega-3: asam dekosakeksanoat (DHA) 0,09\%; asam eikosapentanoat (EPA) $0,03 \%$ dan asam linolenat (HUFA) 0,21\%; kelompok asam lemak omega 6: asam linoleat (LA) $0,25 \%$ dan arakidonat (AA) $0,04 \%$. Tepung ikan molly secara kuantitas dan kualitas sangat baik sebagai bahan pakan sumber protein, asam amino dan asam lemak esensial.

\section{UCAPAN TERIMA KASIH}

Ucapan terima kasih disampaikan kepada Universitas Muslim Indonesia melalui Lembaga Penelitian dan Pengembangan Sumberdaya (LP2S) yang telah mendanai terlaksananya kegiatan penelitian ini.

\section{DAFTAR PUSTAKA}

Abdullah A, Nurjanah, Hidayat T, Yusefi Y. 2013. Profil asam amino dan asam lemak kerang bulu (Anadara antiquata). Jurnal Pengolahan Hasil Perikanan Indonesia. 16(2): 159-167.

Abdullah A, Nurjanah, Hidayat T, Chairunisah R. 2017. Karakteristik kimiawi dari daging kerang tahu, kerang salju dan keong macan. Jurnal Teknologi Industri Pangan. 28(1):74-84.

Arrahman Nr. 2018. Kajian awal senyawa fungsional fenilalanin, lisin dan leusin pada minuman jeli Ikan Lele (Clarias sp.) selama penyimpanan Skripsi. Program Studi Teknologi Pangan, Fakultas Teknik Universitas Pasundan Bandung.

AsdaryM,PrastowoD, Yuliana, Kusumaningrum I. 2019. Pembesaran Kakap Putih (Lates calcalifer) dengan sistem resirkulasi raceway. Jurnal Perekayasaan Budidaya Air Payau dan Laut, 14:64-70.

[BSN] Badan Standardisasi Nasional. Kualitas Tepung Ikan. 01-2715-1996. Jakarta : Badan Standardisasi Nasional.

Boniran S. 1999. Quality control untuk bahan baku dan produk akhir pakan ternak. Kumpulan Makalah Feed Quality Management workshop. American
Soybean Association dan Balai Penelitian Ternak, hlm 2-7.

Damayanti A. 2005. Kajian pemanfaatan beberapa ikan laut dalam perairan barat sumatera sebagai sumber pangan dan obat-obatan. [Skripsi]. Bogor: Fakultas Perikanan dan Ilmu Kelautan. Institut Pertanian Bogor, 105 pp.

Edison T. 2009. Amino Acid: Esensial for Our Bodies. http://livewellnaturally. com. [Diakses 25 Agustus 2020].

Fahmi. 2000. Beberapa jenis ikan pemangsa di tambak tradisional dan cara penanganannya. Oseana, 15(1): 21 - 30.

Fagbenro OA, Nwanna LC, Adebago OT. 1999. Dietary arginine requirement of the African catfish, Clarias gariepinus. Journal of Applied Aquaculture, 9: 59-64.

Furuichi M. 1988. Dietary Requirement. In Fish Nutrition and Mariculture. By T. Watanabe (Ed.). Kanagawa International Fisheries Training Centre. Japan International Cooperation Agency (JICA). Japan Guillaume, p39 - 47.

Gultom OW, Lestari S, Nopianti R. 2015. Analisis Proksimat, Protein Larut Air, dan Protein Larut Garam pada Beberapa Jenis Ikan Air Tawar Sumatera Selatan. Jurnal Teknologi Hasil Perikanan, 4(2):120-127.

Harding DE, Allen OW Jr, Wilson RP. 1977. Sulfur amino acid requirement of channel catfish: L-methionine and L-cystine. Journal of Nutrition, 107: 2031-2035.

Harli M. 2008. Asam Amino Esensial. http://www.suparmas.com. [diakses 25 Agustus 2020]

Hafiluddin, Perwitasari Y, Budiarto S. 2014. Analisis kandungan gizi dan bau lumpur Ikan Bandeng (Chanos chanos) dari dua lokasi yang berbeda. Jurnal Kelautan, 7(1):33-44.

Hepher B. 1990. Nutrition of pond fishes. Cambridge University Press. Cambrige, $388 \mathrm{pp}$.

Halver JE. 2002. Fish Nutrition. 3rd Edition. Academic Press. New York and London. $500 \mathrm{pp}$.

Husni A, Brata AK, Budiyanti SA. 2005. Peningkatan daya simpan ikan kembung dengan ekstrak etanolik Padina sp. 
selama penyimpanan suhu kamar. Jurnal Pengolahan Hasil Perikanan Indonesia, 18(1):1-10.

Ihu MZ. 2011. Kebutuhan protein dan rasio energi protein dalam pakan juvenil ikan kuwe Caranx melampygus. [Tesis]. Bogor: Sekolah Pascasarjana Institut Pertanian Bogor. 76 pp.

Ikhfa. 2017. Pengaruh komposisi media terhadap produksi cacing tanah (Lumbricus rubellus) untuk bahan pakan sumber protein. [Tesis]. Padang: Universitas Andalas. 38 pp.

Jacoeb AM, Nurjanah, Hidayat T, Perdiansyah R. 2020. Komposisi kimia dan profil asam lemak ikan layur segar penyimpanan suhu dingin. Jurnal Pengolahan Hasil Perikanan Indonesia. 23(1): 147-157.

Jangkaru Z. 1974. Makanan Ikan. Lembaga Penelitian Perikanan Darat. Direktorat Jendral Perikanan. Bogor, 45 pp.

Johnson FN. 1981. The use of fish in studying the behavioral effects of lithium. Pharmacopsychiatry. 14(6): 208-12.

Jauncey K. 1983. The effects of varying protein levels on the growth, food conversion, protein utilization and body composition of juvenile tilapias (Sarotherondon mosambicus). Aquaculture, 27: 43-54.

Kusumaningrum I, Sutono D, Pamungkas BF. 2016. Pemanfaatan tulang ikan belida sebagai tepung sumber kalsium dengan metode alkali. Jurnal Pengolahan Hasil Perikanan Indonesia. 19(2): 148-155.

Lovell RT. 1989. Nutrition and Feeding of Fish. Van Nostrand Reinhold, New York, $260 \mathrm{pp}$.

Lockwood JL, Hoopes MF, Marchetti MP. 2007. Invasion ecology. Blackwell Publishing. California, USA. 428 pp.

Mertz ET. 1969. Amino acid and protein requirements of fish. In: Neuhas OW, Halver JE: Fish in research. Academic Press, New York, London: 233-244.

Megawati RA, Arief M, Alamsjah MA. 2012. Pemberian pakan dengan kadar serat kasar yang berbeda terhadap daya cerna pakan pada ikan berlambung dan ikan tidak berlambung. Jurnal Ilmiah Perikanan dan Kelautan, 4(2): 187-192.

Meilisza N, Subamia IW. 2016. Gambaran profil asam amino dalam formulasi pakan ikan pada berbagai rasio tepung maggot dan tepung cacing tanah. Prosiding Seminar Nasional Ikan ke 8, p 147-154.

Miles RD, Chapman FA. 2007. The concept of ideal protein in formulation of aquaculture feeds. Departement of Fisheries and Aquatic Sciences, University of Florida, USA. FA144, p1-3.

Nurjanah, Suseno SH, Hidayat T, Ekawati Y, Paramudhita P, Arifianto. 2015. Change Composisition chemical of skipjack tuna due to frying process. International Food Research Journal. 2(5): 2093-2102

NRC (National Research Council). 1993. Nutrient requirements of fish. National Academy Press, Washington, DC, USA, $114 \mathrm{pp}$.

Parkhurst CR. \& Mountney. 1988. Poultry Meat and Egg Production. Van Nostrand Reinhold, New York, p 110-121.

Puspowardoyo H, \& Djarijah A. 2002. Pembenihan dan Pembesaran Lele Sangkuriang Hemat Air. Kanisius, Yogyakarta, 60 pp.

Prastari C, Yasni S, Nurilmala M. 2017. Karakteristik protein ikan gabus yang berpotensi sebagai antihiperglikemik. Jurnal Pengolahan Hasil Perikanan Indonesia, 20(2): 413-423.

Pratama RI, Rostini I, Rochima E. 2018. Profil asam amino, asam lemak dan komponen volatile ikan gurame segar (Osphronemus gouramy) dan kukus. Jurnal Pengelolaan Hasil Perikanan Indonesia 21(2):218-231.

Rabegnatar INS, \& Nahapari E. 2002. Estimasi kebutuhan kadar protein optimal untuk pertumbuhan benih ikan tawes (Puntius gonionotusl). Jurnal Penelitian Perikanan Indonesia, 8(2):21-29.

Rasyid A. 2003. Asam lemak omega-3 dari minyak ikan. Oseana, 28(3):11-16.

Rahayu M, Pramonowibowo, Yulianto T. 2014. Profil asam amino yang terdistribusi ke dalam kolom air laut pada ikan kembung (Rastrelliger kanagurta) sebagai umpan (skala laboratorium). Journal of Fisheries Resources Utilization Management and Technology, 3(3):238 - 247.

Riry J, Lawalata VN, Tapotubun EJ, Far-Far RA. 2013. Mutu organoleptik produk 
enbal fortifikasi (makanan tradisional Kepulauan Kei) ditinjau dari daya terima konsumen. Jurnal Pengolahan Hasil Perikanan Indonesia. 16(3):259-267

Rukmana R. 1997. Ikan Nila, Budidaya dan Prospek Agribisnis. Penerbit Karnisius, Yogyakarta, $91 \mathrm{pp}$.

Robinson EH, Wilson RP, Poe WE. 1981. Arginine requirementand apparent absence of lysine-arginine antagonist in fingerling channel catfish. Journal Nutrition, 111: 46-52.

Robinson EH, Menghe HLi, \& Bruce BM. 2001. A practical guide to nutrition feeds, and feeding of Catfish. Bull. 1113. Mississippi Agricultural \& Forestry Experiment Station. Mississippi State University, $39 \mathrm{pp}$.

Sahwan MF. 2002. Pakan Ikan dan Udang. Jakarta : Penebar Swadaya, 99 pp.

Samsundari S. 2007. Identifikasi ikan segar yang dipilih konsumen beserta kandungan gizinya pada beberapa pasar tradisional di Kota Malang. Jurnal Protein, 14(1):41-49.

Sitompul S. 2004. Analisis asam amino dalam tepung ikan dan bungkil kedelai. Buletin Teknik Pertanian. 9(1): 33-37.

Sumarjo D. 2009. Pengantar Kimia: Buku Panduan Kuliah Mahasiswa Kedokteran dan Program Strata 1 Fakultas Bioeksakta. Penerbit Buku Kedokteran EGC. Jakarta. $650 \mathrm{pp}$.

Sutikno E, Latief MS, Riza F, Susanti PD, Martijo, Suparjono. 2017. Petunjuk Teknis Teknik Pembuatan Pakan Murah dengan Teknologi Sederhana. Balai Besar
Perikanan Budidaya Air Payau (BBPBAP) Jepara. 24 pp.

Tamsil A \& Hasnidar. 2019. Aspek biologi reproduksi ikan molly, Poecilia latipinna (Lesueur 1821) di tambak Bosowa Kabupaten Maros. Jurnal Iktiologi Indonesia. 19(3): 375-390.

Trilaksani W, Salamah E, Nabil M. 2006. Pemanfaatan limbah tulang ikan tuna (Thunnus sp.) sebagai sumber kalsium dengan metode hidrolisis protein. Buletin Teknologi Hasil Perikanan. 9(2): 34-45.

Utomo NBP, Susan, Setiawati M. 2013. Peran tepung ikan dari berbagai bahan baku terhadap pertumbuhan lele sangkuriang (Clarias sp.). Jurnal Akuakultur Indonesia. 12 (2): 158-168.

Vijayan DK, Jayarani R, Singh DK, Chatterjee NS, Mathew S, Mohanty BP, Sankar TV, Anandan R. 2016. Comparative studies on nutrient profiling of two deep sea fish (Noepinnula orientalis) and (Chlorophthalmus corniger) and brackish water fish (Scatophagus argus). The Journal of Basic and Applied Zoology. 77:41-48.

Watanabe T. 1988. Fist Nutrion and Marine Culture. Department of Aquatic Biosciene. Tokyo University of Fisheries. JICA. p. 79-82.

Yuliani, Marwati, Wardana H, Emmawati A, Candra KP. 2018. Karakteristik kerupuk ikan dengan subsitusi tepung tulang ikan gabus (Channa striata) sebagai fortifikan kalsium. Jurnal Pengolahan Hasil Perikanan Indonesia. 21(2): 258-265. 